\title{
SURVEY RESEARCH ABOUT THE IMPORTANCE OF ENGLISH FOR YOUNG LEARNERS AT ELEMENTARY SCHOOLS
}

\author{
Ayu Oktaviani ${ }^{1}$ \\ STKIP PGRI Lubuklinggau \\ Putra Saparingga ${ }^{2}$ \\ STKIP PGRI Lubuklinggau \\ Dwi Susanto 3 \\ STKIP PGRI Lubuklinggau \\ ayuoktaviani08@gmail.com ${ }^{1}$
}

Submit, 14-03-2019 Accepted, 27-06-2019 Publish, 27-06-2019

\begin{abstract}
The objective of the research was to find out teachers' perceptions about the importance of English for young learners at Elementary Schools in Lubuklinggau.Type of survey used in this study was cross-sectional survey research. To select the sample, cluster random sampling used in this research. Cluster random sampling here focused on the eight (8) districts of Lubuklinggaucity (Lubuklinggau Utara1-2, Selatan1-2, Barat1-2 and Timur1-2). The researchers chose randomly four (4) districts. The researcher used the representative sample from each districts chosen. 100 teachers, 100 students, and 100 parents are samples. The researcher used survey research and the data were collected by using questionnaire and interview. Technique for analyzing the data used simple basic statistical technique. The data are scored by using Likert scale. The results of the research were: 1) the respondents agree that the children who learn foreign language early as possible will get the better result. 2) the respondents very agree that economic globalization has pushed the necessity of workers who are able to speak English. 3) the respondents agree that the enthusiasm of parents in supporting their children to learn English hopefully can help their children will have social and economic benefits in the future. Based on the result of the data, it can be concluded that the teachers, students and parents of Elementary Schools in Lubuklinggau agree that English for Young Learners is important.
\end{abstract}

Keyword: survey, english for young learner, elementary schools 


\section{INTRODUCTION}

Since 2000, it has been goverment policy in Lubuklinggau city and Musi Rawas regency to introduce English in Grade 5 of Elementary schooling (when learners are generally age 11). In addition, English is a new subject in many Elementary schools of Lubuklinggau area. Today, English in Lubuklinggau is "local content". It proves on decentralization of education in Indonesia has encouraged the local governments to make their own decisions relative to some portion of curricular space in the use of some learning hours that has become known as "local content" (Musthafa 2010:1). In shortly, English is not majority subject to the primary levels. The teachers teach English as the additional subject as the local content.

In oppositely, English is a king of the languages in the world. Students live in Technology and Information era that needs English as the primary language. Not only IT era, ASEAN Economic Community has been implemented also in Indonesia, but also where all ASEAN countries have to compete each other in order to be not isolated. Facing this condition, the countries have some challenges to be solved. In another opinions, Indonesian government has realized that English is important for the country's development, especially in the effort of human resource development. Therefore, as a policy, the government has published Law Regulation No. 20 in 2003 about National Education System and Government Regulation No. 19 in 2005 about Standard of National Education. These policies are used as the guideline for all education components in conducting the Indonesian education system.

Based on the explanations above, English is a tool to improve human resource, communication, a way to see others countries and also english is needed for every circles and ages. Especially, English is important for young learners. (Brown, 2007:101) stated that popular tradition wuld have you believe that children are effortless second language learners and far superior to adults in their eventual success). In addition, Supriyanti (2012:65) conducted her research about why the children need to learn English at Elementary Schools. The result of the research showed that there were several reasons why the children need to learn English in Elementary Schools. The reasons were the widespread assumption that the children are better than adults in learning a new language, the fact that economic globalization has pushed the demand of English in the form of workforce who speak English, and the parents' enthusiasm for their children to learn English early in order to have social and economical benefits.

To solve the world phenomena, EYL (English for young learner) is important to apply in Elementary school in each level in Indonesia, especiall Lubuklinggau. Suyanto (2008:15), Indonesian young learners are elementary schools students between 6 to 12 years old children. They are divided into two 
groups, younger group (6 to 8 years old) and older group (9 to 12 years old). Whereas, based on level, they are called Lower Classes, the students of grade 1, 2 and 3 and Upper Classes, the students of grade 4, 5 and 6.

In preparation, the young learners of Indonesia should prepare their intelegent and future life to have better future by using English. In fact, English is needed in every pieces of the world's phenomena.Concerning to the facts and the reasons above, the researchersare interested in doing a research entitled "Survey research about the Importance of English for Young Learners at Elementary Schools in Lubuklinggau city". The researchers state that the objective of the research is to find out the perceptions about the importance of English for young learners at Elementary Schools in Lubuklinggau.

\section{LITERATURE REVIEW}

\section{The Concept of Young Learners}

When the people talk about English for Young Learners (EYL), they need to understand who young learners are. Young learners are the young age students who learn English. There are three groups of young learners based on their age and grade. First group is very young learners, they are 3-6 years old (pre-school education), second group is young learners, they are 7-9 years old $\left(1^{\text {st }}-3^{\text {rd }}\right.$ grade $)$, and the third group is older/late young learners, they are 10-12 years old $\left(4^{\text {th }}\right.$ $6^{\text {th }}$ grade).

In Indonesia, English young learners are the students of elementary school who learn English as additional subject or local content. According to Suyanto (2008:15), Indonesian young learners are elementary schools students between 6 to 12 years old children. They are divided into two groups, younger group (6 to 8 years old) and older group (9 to 12 years old). Whereas, based on level, they are called Lower Classes, the students of grade 1, 2 and 3 and Upper Classes, the students of grade 4, 5 and 6.

Based on the definition of young learners above, it can be concluded that young learners are differed from adolescents and adults. Children or young learners are unique, because they have their own way to learn. Harmer (2007:82) emphasized that young learners learn differently from older in the following ways: 1) they respond to meaning even if they do not understand individual words; 2) they often learn indirectly rather than directly; 3) their understanding comes not just from explanation, but also from what they see and hear and, crucially, have a chance to touch and interact with; 4) they find abstract concepts such as grammar rules difficult to grasp; 5) they generally display an enthusiasm for learning and curiousity about the world; 6) they have a need for individual attention and approval from the teacher; 7) they are keen to talk about themselves and respond well to learning that uses themselves and their own livesas main 
topics in the classroom; 8) they have a limited attention span; unless activities are extremely engaging, they can get easily bored, losing interest after ten minutes or so.

Young learners around the world have difference characteristics. They learn in difference condition and difference ways. According to Supriyanti (2012:2), Indonesian elementary school children have some characteristics as follow:

1. Most of them live in less geographically advantaged areas where education facilities in the form of human resources (teachers and officials), access to media and progress are not readily available. They live in every village, sub district, district, regency and province all over the country which is still struggling with the equity of opportunities in having access to education. Some who live in the remote places, no matter how wealthy their parents are, access to education could not be as easy to get as for those living in the cities. While those who live in the cities whose parents do not come from middle or high economic background still have difficult access to the quality education.

2. Due to the fact that elementary schools are of the lowest level of education, elementary schoolchildren in Indonesia generally reflect the real lives of the society. If they live in areas where the people have high standard of living, the schoolchildren that are found will be healthy, happy and well taken care of. On the other hand, when the schools are in the less economically, socially or geographically disadvantaged areas, elementary schoolchildren who are found will be those looking hungry or unhealthy.

3. Since 2001 it as when provincial autonomy was launched elementary schools in Indonesia has been under the local government. It implies that the better the local government the better the lives of the elementary schoolchildren are. Equipped with better teachers and better facilities as well as better management, schools in more privileged areas will certainly provide better service and better schooling to the children. In other words, children in elementary schools portray the condition of the areas.

4. Education in the lowest level and in the youngest age naturally carry with them the home or domestic problems which influence the children's condition in every way especially in their learning situation. Children with domestic problems generally will also have the learning problems which teachers should take into account in order to have the best possible potential for success in their teaching. In other words children in our elementary schools generally have learning problems in schools which correlate with their home conditions.

5. The children do not have the option whether to learn English or not. Their parents, most often are as helpless as their children, cannot do anything about 
it. What they have to learn or not to learn are decided by the authority whether national or local. Schools individually are not free either to provide or not provide English to the children as a local content subject. The decision is made by the local authority in the education office. Whether or not the children learn English will be decided by those who will not see the school as individuals.

\section{The Importance of English for Young Learners}

English is a very important element for children self-development, especially when it deals with their cultural entity. By learning English, of course children will also automatically learn about its culture which then will affect children's point of view towards life. Furthermore, by learning English, children will also influenced by the high culture habits that brought into its cultural elements such as reading habit, healthy life habit, and such. According to Nishida (2008:4), the reason why learning a foreign language is introduced in elementary schools is to deal with globalization. It is not only required in society but also thought of as a chance to establish our identity through communication with foreigners. Moreover, elementary school students are extremely interested in new things and are at a stage where they can naturally absorb other cultures through language.

In addition, why English is important for young learners, it can be figured out from the theory by Supriyanti (2012:4). She stated that there are three reasons for providing English in the elementary schools.

1. Firstly, the widespread assumption that the younger the child learns a new language the better the result will be. Most people agree with this assumption, because the child is in golden age learner. According to Lightbown\&Spada (1999:29), the child has a superior ability in acquiring the sets or units of language, because the child is in golden age period due to plasticity and virginity of their brain.

2. Secondly, the fact that economic globalization has pushed the demand of English in the form of the workforce who speak English to meet the need of the international economic forces. In the business world that more globalized, many local Indonesian companies enter into the world market, and many international companies enter the local market. The use of English is becoming a necessity as the language of business. Therefore the people often find out a job vacancy in the website or newspaper, one of the criteria is able to speak English. It means that an applicant has to master English both passively and actively in order to face the international economic forces.

3. The last, the parents are enthusiasm for their children to learn English early in order to have social and economical benefit in the national context. The 
parents realize that English is very important for their children. Therefore, the parents want their children to learn English at school, teach by them self at home, and they also willing to spend some money for their children to learn English in the course. These efforts are done by the parents with hope their children will have social and economical benefit in the national context.

From the explanations above, it can be concluded that English is very important and very helpful and very useful for young learners in Indonesia because it has so many functions and beneficial usages in helping them to engage with global life.

\section{RESEARCH METHOD}

Type of survey used in this study was cross-sectional survey research. This type collects information from samples that has been drawn from predetermined at just one point in time, although the time took to collect the data may take anywhere from a day to a few weeks or more.To select the sample, cluster random sampling used in this research. Cluster random sampling here focuses on the eight districts of Lubuklinggau city that have explained before. The researchers will choose randomly four (4) districts. After getting the districts, the researcher will calculate the total number of elementary teachers from the four districts chosen. The researcher used the representative sample from each districts chosen. 100 teachers, 100 students, and 100 parents are samples. The reseachers use triangulation resources or subjects to know the credibility of data(Sugiyono, 2010:274). There are three resources, they are Teachers, Students, and Parents .

The most common types of instruments used in survey research are questionnaire and interview schedule. Therefore, the researchers used both of the instruments to get the data from the samples.

\section{FINDING}

The questionnaire contained 3 indicators from Supriyanti (2012:89), they were: 1) the widespread assumption that the younger the child learn a new language the better the result will be, 2) the fact that economic globalization has pushed the demand of English in the form of workforce who speak English to meet the need of the international economic forces, 3) the parents' enthusiasm for their children to learn English early in order to have social and economical benefit in the national context.

Based on the two instruments above, the researcher found out teachers, students, and parents' perception about the importance of English for Young Learner that were investigated 100 parents, students and teeachers in Lubuklinggau (4districts). The results of the questionnaires were showed in the analysis of teachers, students, and parents' perception table inappendices 1, 2, and 
3. Then, the data were described per each item and supported by the result of interviews as follow.

\section{Teachers' Perception about the Importance of English for Young Learner at Elementary School in Lubuklinggau City}

1. Every child should be able to learn English as supporting skill for their future.Based on the responses from the 100 respondents about every child should be able to learn English as supporting skill for their future, it could be seen that there were $68(68 \%)$ respondents very agree and 32 respondent $(32 \%)$ agree. It showed that the teachers as the respondents very agree that English is a supporting skill for children's to get their future.

2. English is one of the important subjects that are taught in the Elementary school.Based on the responses from 100 respondents about English is one of the important subjects that is taught in the Elementary school, it could be seen that there were $36(36 \%)$ respondents veryagree, 63 (63\%) agree and $1(1 \%)$ disagree. It showed that the teacher as the respondents agree that English is one of important subjects taught in the Elementary school.

3. English is suggested to be taught in the Elementary school environment and the aim is the student should have basic in foreign language.Based on the responses from 100 respondents about English is suggested to be taught in the Elementary school, it could be seen that there were $53(53 \%)$ respondents very agree and $47(47 \%)$ agree. It showed that the teacher as the respondents very agree that English was suggested to be taught in the Elementary school, and the aim is student would have basic in foreign language.

4. If learning English is done earlier, the result will be better.Based on the responses from 100 respondents about in learning English is done earlier, so the result will be better, it could be seen that there were $53(53 \%)$ respondents very agree and 47 (47\%) agree. It showed that the teachers as respondents very agree that English isbe learned earlier,then the result would be better.

5. In the globalization era, English is one of components are needed to support communication with foreigner.Based on the responses from the 100 respondents about in the globalization era, English is one of components needed to support communication with foreigner, it could be seen that there were $47(47 \%)$ respondents very agree and 53 (53\%) agree. It showed that the teachers as the respondentsagreethat English is one of components needed to support communication with foreigner to face the globalization era.

6. English is commonly language that should mastered by people around the world.Based on the responses from the 100 respondents about English is the most commonly language that is mastered by people around the world, it could be seen that there were 36 (36\%) respondents very agree, 57 (57\%) agree, 
and $7(7 \%)$ disagree. It showed that the teachers as the respondents agree that English is the most commonly language mastered by people around the world.

7. In ASEAN Economic Community era, the neccesity of English has been increased, the workers have to master about English.Based on the responses from the 100 respondents about in ASEAN Economic Community era, the necessity of English has been increased, the workers have to master about English, it could be seen that there were 46 (46\%) respondents very agree, 51 (51\%) agree, and $3(3 \%)$ disagree. It showed that the teachers as the respondents agree that necessity of English has been increased and the workers had to master about English in ASEAN Economic Community era.

8. In the economic globalization era, workers are demanded to be able to learn English in order to compete internationally.Based on the responses from the 100 respondents about in the economic globalization era, workers are demanded to be able to learn English in order to compete internationally, it could be seen that there were $41(41 \%)$ respondents very agree, $56(56 \%)$ agree and3 (3\%) disagree. it showed that the teachers as the respondents agree that worker needed to be able to speak English in order to compete internationally.

9. The ability of mastering English for children cannot be separated from the parents' roles that facilitate their children to learn English.Based on the responses from the 100 respondents about the ability of mastering English for children cannot be separated from the parents' role that facilitate their children to learn English, it could be seen that there were 32 (32\%) respondents very agree, $65(65 \%)$ agree and $3(3 \%)$ disagree. it showed that the teachers as the respondents agree that the parents had an important role to guide and facilitate the children in learning English.

10. Parents are expected can support the students in teaching and learning English at Elementary school in order they could know the basic of English.Based on the responses from the 100 respondents about the parents are expected can support the students in teaching and learning English at Elementary school in order they could know the basic of English, it could be seen that there were 46 (46\%) respondents very agree, 51 (52\%) agree, 2 (2 $\%)$ disagree, and $1(1 \%)$ very disagree. It showed that the teachers as the respondents agree that one of reasons why the parents very supported their childrem to learn English at Elementary school was the children could recognize the basics of English.

11. Many parents that want their child to learn English earlier, the school should give well facilitate for children in order to get Basic English material in Elementary school.Basedon the responses from the 100 respondents about many parents that want their child to learn English earlier, the school should 
give good facilitate for children in order to get basic English material in Elementary school, it could be seen that there were 32 (32\%) respondents very agree, $63(63 \%)$ agree, and 4 (4\%) disagree, and 1 (1\%) very disagree. It showed that the teachers as the respondents agree that many parents expected school should give well facilitated for children in order to getbasic English material in Elementary school.

12. Every parent is expected to have enthusiasm or seriousness in supporting their children to learn English.Based on the responses from the 100 respondents about every parent is expected to have enthusiasm or seriousness in supporting their children to learn English, it could be seen that there were $31(31 \%)$ respondents very agree, 65 (65\%) agree, 2 (2\%) disagree, and 2 ( $2 \%$ ) very disagree. It showed that the teachers as the respondents agree that the parent is expected to have enthusiasm in supporting their children to learn English.

\section{Students' Perception about the Importance of English for Young Learner at Elementary School in Lubuklinggau City}

1. I Learn English in order to speaking English fluently. Based on the responses from 100 respondents about I learn English in order to speaks English fluently, it could be seen that there 98 (98\%) respondents very agree and 2 (2 $\%)$ agree. It showed that the students as the respondents very agree learnt English in order to speak fluently.

2. I Learn English because I do not master English vocabulary. Based on the responses from 100 respondents about I learn English because I do not master English vocabulary, it could be seen that there $55(55 \%)$ respondents very agree, 38 (38\%) agree, 6 (6\%) disagree, and 1 (1\%) very disagree. It showed that the students as the respondents very agree learning English to be mastered English vocabulary.

3. I want to be able to communicate with foreigner in English so I learn English. Based on the responses from 100 respondents about I want to be able to communicate with foreigner in English so I learn English, it could be seen that there $85(83,33 \%)$ respondents very agree, $8(8,97 \%)$ agree, and $7(5,12$ $\%)$ disagree. It showed that the students as the respondents very agree I want to be able to communicate with foreigner in English so I learn English.

4. I learn English because I have difficulty in speaking English. Based on the responses from 100 respondents about I learn English because I have difficulty in speaking English, it could be seen that 70 (70\%) respondents very agree, $20(20 \%)$ agree, 8 (8\%) disagree, and 2 (2\%) very disagree. It showed that the students as the respondents very agree learning English because I have difficulty in speaking English. 
5. Learning English can help me to understand foreign term in public area. Based on the responses from 100 respondents about Learning English can help me to understand foreign term in public area, it could be seen that there $74(74 \%)$ respondents very agree, 15 (15\%) agree, and11 (11\%) disagree. It showed that the students as the respondents very agree learning English to help understand foreign term in public area.

6. I learn English to add about daily activity vocabulary. Based on the responses from 100 respondents about I learn English to add about daily activity vocabulary, it could be seen that there 63 (63\%) respondents very agree, 20 (20\%) agree, 9 (9\%) disagree and 8 (8\%) very disagree. It showed that the students as the respondents very agree learning English to add daily activity vocabulary.

7. I learn English because I do not understand the meaning of English sentence . Based on the responses from 100 respondents about I learn English because I do not understand the meaning of English sentence, it could be seen that there $67(67 \%)$ respondents very agree, 25 (25\%) agree, $6(6 \%)$ disagree and $2(2 \%)$ very disagree. It showed that the students as the respondents very agree learning English to understand the meaning sentence in English.

8. I learn English because I have difficulty in writing essay in English. Based on the responses from 100 respondents about I learn English because I have difficulty in writing essay in English, it could be seen that there 57 (57\%) respondents very agree, 24 (24\%) agree, $16(16 \%)$ disagree and $3(3 \%)$ very disagree. It showed that the students as the respondents very agree learning English because have difficulty in writing essay in English.

9. I learn English because I want to go abroad. Based on the responses from 100 respondents about I learn English because I want to go abroad, it could be seen that there $74(74 \%)$ respondents very agree, $17(17 \%)$ agree, 7 (7\%) disagree and 2 (2\%) very disagree. It showed that the students as the respondents very agree learning English because to go abroad.

10. I learn English to make happy my parents. Based on the responses from 100 respondents about Learn English to make happy my parents, it could be seen that there $78(78 \%)$ respondents very agree, $17(17 \%)$ agree, $4(4 \%)$ disagree and 1 ( $1 \%)$ very disagree. It showed that the students as the respondents very agree learning English because want to make happy their parents.

11. I have difficulty in reading text that's why I am interested to learn English.Based on the responses from 100 respondents about I have difficulty in reading text that's why I am interested to learn English, it could be seen that there $72(72 \%)$ respondents very agree, 22 (22\%) agree, and6 (6\%) disagree. It showed that the students as the respondents very agree learning 
English because have difficulty in reading text, so the students interested to learning English.

12. I learn English because I want work in abroad. Based on the responses from 100 respondents about because I learn English because I want work in abroad, it could be seen that there $62(62 \%)$ respondents very agree, 27 (27\%) agree, $9(9 \%)$ disagree and $2(2 \%)$ very disagree. It showed that the students as the respondents very agree learn English because want work outside of the country.

\section{Parents' Perception about the Importance of English for Young Learner at Elementary School in Lubuklinggau City}

1. Like the other subject, English is also necessary to be taught for students in primary level.Based on the responses from the 100 respondents about like another subject, English is also necessary to be taught for students in primary level, it could be seen that there were $84(84 \%)$ respondents very agree, 15 (15 $\%)$ agree, and $1(1 \%)$ disagree. It showed that the parents as the respondents very agree that English need to be taught in Elementary school like the other subject.

2. Learning English earlier can help someone for mastering English.Based on the responses from the 100 respondents about learning English earlier can help someone for mastering English, it could be seen that there were 41 (41\%) respondents very agree and 59 (59\%) agree. It showed that the parents as the respondents agree that learning English earlier could helped someone for mastering English.

3. Learning English in high school level will be more optimal for the students.Based on the responses from the 100 respondents about learning English in high school level will be more optimal for the students, it could be seen that there were 43 (43\%) respondents very agree, 36 (36\%) agree, 11 (11 $\%)$ disagree, and $10(10 \%)$ very disagree. It showed that the parents as the respondents very agree that learning English in high school level would be more optimal for the students.

4. Inuring children to speak English in family environment is needed to increase children's ability in speaking English.Based on the responses from the 100 respondents about inuring children to speak English in family environment is needed to increase children's ability in speaking English, it could be seen that there were 57 (57\%) respondents very agree, 40 (40\%) agree, and $3(3 \%)$ disagree. It showed that the parents as the respondents agree that inuring children to speak English in family environment is needed to increase children's ability in speaking English. 
5. In the globalization era, mastery of English is one necessary factor to facilitate communication process withforeigner.Based on the responses from the 100 respondents about in the globalization era, mastery of English is one necessary factor to facilitate communication process with foreigner, it could be seen that there were 47 (47\%) respondents very agree, 49 (49\%) agree, 3 (3\%) disagree, and 1 ( $1 \%$ ) very disagree. It showed that the parents as the respondents very agree that in the globalization era, mastering English was one of factors needed to supported communication with foreigner.

6. Beside skills to facing international trade, mastering English is also necessary as majority that used in international communications. Based on the responses from the 100 respondents about beside skills to facing international trade, mastering English is also necessary as majority that used in international communication, it could be seen that there were $47(47 \%)$ respondents very agree, 46 (46\%) agree, and 7 (7\%) disagree. It showed that the parents as the respondents agree that beside skills to facing international trade, mastering English was also necessary as majority that used in international communication.

7. Nowadays, the acquisition in speaking English does not give big effect for someone to get job.Based on the responses from 100 respondents about Nowadays, the acquisition in speaking English does not give big effect for someone to get job, it could be seen that $41(41 \%)$ respondents very agree, 27 (27\%) agree, $13(13 \%)$ disagree and $19(19 \%)$ very disagree. It showed that the parents as the respondents very agree the acquisition in speaking English does not give big effect for someone to get job.

8. Has a capability in speaking English can give great advantages for modern workers.Based on the responses from 100 respondents about Has a capability in speaking English can give great advantages for modern workers, it could be seen that $53(53 \%)$ respondents very agree, 38 (38\%) agree, $6(3,35 \%)$ disagree and $3(3 \%)$ very disagree. It showed that the parents as the respondents very agree that why English must mastered because English have big advantages for modern workers

9. The ability of English children cannot be separate from the parents' role who guidance and facilitate their children to learn English. Based on the responses from 100 respondents about The ability of English children cannot be separate from the parents' role who guidance and facilitate their children to learn English, it could be seen that there 79 (79\%) respondents very agree, 16 (16\%) agree, 1(1\%) disagree, and $4(4 \%)$ very disagree. It showed that the parents as the respondents very agree that the parents had an important role to guide and facilitate the children in learning English. 
10. Parents' think that children's time are spent by playing and learning. Guiding children to learn English is something which can be done after they already understand the benefit of the language itself.Based on the responses from 100 respondents about Parents' think that children's time are spent by playing and learning .Guiding children to learn English is something which can be done after they already understand the benefit of the language itself, it could be seen that $33(33 \%)$ respondents very agree, 55 (55\%) agree, 11 (11 $\%)$ disagree, and $1(1 \%)$ very disagree. It showed that the parents as the respondents agree that way the parent's Guide children to learn English is something which can be done after they already understand the benefit of the language itself

11. Forcing the students to join the course is ordinary things. Based on the responses from 100 respondents about Forcing the students to join the course is ordinary things, it could be seen that 46 (46\%) respondents very agree, 52 (52\%) agree and $2(2 \%)$ disagree. It showed that the parents as the respondents agree that forcing the students to join the course is ordinary things

12. In learning English earlier, parents can expect that their children can have better social and economic for their future world. Based on the responses from 100 respondents about In learning English earlier, parents can expect that their children can have better social and economic for their future world, it could be seen that there 54 (54\%) respondents very agree, 38 (38\%) agree, $5(5 \%)$ disagree and $3(3 \%)$ very disagree. It showed that the parents as the respondents very agree that why children must mastery English because can give social and economic advantages in the future.

\section{DISCUSSION}

The researcher used the questionnaire which was formed based on the 3 indicators by Supriyanti (2012:67). The indicators were 1) The widespread assumption that the younger the child learn a new language the better the result will be, 2) The fact that economic globalization has pushed the demand of English in the form of the workforce who speak English to meet the need of the international, 3) The parents' enthusiasm for their children to learn English early in order to have social and economical benefit in the national context economic forces.

In the questionnaire, each indicator contained 4 items in the form of expressions which were scored by using Likert scale. Meanwhile, the interview contained 3 questions were related to the 3 indicators. These indicators had answered the formulation of the problem in chapter I. These answers were 
determined as the results of the investigation that would be discussed in the following.

The results of the 4 items in the first indicator show that the respondents agree that the children who learn foreign language early as possible will get the better result. It is supported by the interviews to the respondents. The teachers, students and parents as the respondents argued that if the children learnEnglish early, the children will be easier to receive the material.

Based on the results of the instruments and the theory above, it can be concluded that English for Primary Schools is important. Becausethe children acquire and learn English better. The children are easy to receive the English material and also have the ability to memorize well. Furthermore, by learning English early, the children will have basics of English skill. At least, they will master the basics of English that will be useful in the next level of junior and senior high school education.

In addition, from the answers by the respondents toward the four items in the second indicator, it can be assumed that the Primary School teachers, students and parents in South Lubuklinggauvery agree that economic globalization has pushed the necessity of workers who are able to speak English. It is also supported by the interviews to the respondents. The respondents said that Indonesian workers have to master the English skill in order to face the economic globalization era.

Moreover, the country is facing the ASEAN Economic Community Era where the international workers must have the competences. One of the competences have to be mastered is English skill. English skill for the workers will be useful in supporting the communication where many the negotiations are delayed or canceled because of the employees who can not speak English fluently.

Based on the results of the instruments and the theory above, it can be concluded that English for Primary School is very important with the reason English will be useful for the future of children for facing the competition in the workforce. By mastering English, the children will have the advantage in applying a job in the future. Because there are many companies especially the foreign companies has the regulation where the workers have to master English.

The last, from the answers by the respondents of the four items in the third indicator, it can be assumed that the Primary School teachers, students and parentsin Lubuklinggau agree that the enthusiasm of the parents in supporting their children to learn English, because the parents hope their children will have social and economic benefits in the future. It is supported by the interviews to the respondents. The teachers, students and parents of Primary schools in Lubuklinggau as the respondents assumed that the parents have begun to interest in supporting and facilitating their children to learn English in the courses. 
English is important for the future of children. The children will have many advantages by mastering English in the next time. According to Nishida (2008:4), the reason why learning a foreign language is introduced in elementary schools is to deal with globalization. It is not only required in society but also thought of as a chance to establish our identity through communication with foreigners. Therefore, for primary school childrens, English will have many functions and beneficial usages in helping them to engage with global life.

Based on the results of the instruments and the theory above, it can be concluded that English for Young Learner is important. The reason is the children will have social and economic benefits in the future by mastering English. Theyare going to have more chance to have many friends from abroad and the young learners willbe easy to apply a job and then impacts to the economic benefits for them.

From the results of 3 indicators both the answers in the questionnaire and the answers in the interviews, the resarcher can conclude that English for young learner is important. It can be showed from the implementaion of English teaching and learning in the Primary Schools. According to Jenkins (2015:41), many countries begin English subject at the primary level, and students are studying the language at younger and younger ages.

Since last decade, English is started to be taught at Primary Schools as a local content. It is taught from the third grade till the sixth grade.Eventhough English is just taught as a local content, it is enough to prove that English is needed by children in primary school. It means that English is important for Young Learner.

\section{CONCLUSION}

The researcher concluded that the teachers, students and parents of Elementary Schools in Lubuklinggau agree that English for Young Learners is important. Based on the results of the instruments, that were the answers of the respondents in the questionnaire and interview, the researcher found several reasons that supported why English for Young Learners isimportant.The teachers, students and parents of Elementary Schools in Lubuklinggau assumed that English for Young Learners is important because of if the young learners learn English early, the result would be better, English would be useful for the young learners to get a job in the future, and by mastering English, the young learners would have the social and economic benefits in the future. Therefore, the researcher concluded that the teachers, students and parents of Elementary Schools in Lubuklinggauagree that English for Young learners is important. 


\section{REFERENCES}

Brown, H. D. (2007). Principles of Language Learning and Teaching (5 ${ }^{\text {th }}$ Ed.). San Francisco: Pearson Education Inc.

Harmer, J. (2007).The Practice of English Language Teaching ( $4^{\text {th }}$ Ed.). Essex: Pearson Longman.

Jenkins, J. (2015). Global English: A resource book for students ( $3^{\text {rd }}$ Ed). London: Routledge.

Lightbown, P. M. \&Spada, N. (1999).How languages are learned. Oxford: OUP. Musthafa, B. (2010). Teaching English to Young Learners in Indonesia: Essential Requirements.Depok: Indonesia University of Education. Retrieved from http://file.upi.edu/Direktori/JURNAL/EDUCATIONIST/Vol._4

Juli_2010/07_Bachrudin_Musthafa.pdf.

Nishida, H. (2008). Elementary School English Education: The Present Condition of the Japanese Education System. Tokyo: Kairyuudou.Retrieved from https://www.kansai-u.ac.jp/fl/publication/pdf_forum/5/081nishida.pdf.

PeraturanPemerintah tentang Standar Pendidikan Nasional.(n.d.).Retrieved May 25, 2016, from https://kemenag.go.id/file/dokumen/PP1905.pdf.

Sugiyono (2010).MetodePenelitianKuantitatif, Kualitatifdan R\&D. Bandung: Alfabeta

Supriyanti, N. (2012). Why do Our Chlidren Need to Learn English at Elementary Schools? A Critical Review on the Provision of English to the Indonesia Elementary Schools. Yogyakarta: UniversitasNegeri Yogyakarta. Retrieved from http://eprints.umk.ac.id/340/21/PROCEEDING_TEYLIN_2.152-158.pdf.

Suyanto, Kasihani K.E. (2008). English for Young Learners. Jakarta: PT BumiAksara. 